\title{
OVULATION RATE IN GILTS AFTER SHORT-TIME EXPOSURE TO CONTINUOUS LIGHT*
}

\author{
D. G. WADDILL, G. H. GHANEY AND R. H. DUTT \\ Department of Animal Sciences, University of Kentucky, \\ Lexington, Kentucky, U.S.A.
}

(Received 17th March 1967, revised 31st August 1967)

\begin{abstract}
Summary. Ovulation rate in gilts maintained under continuous light (daylight plus 118 to 130 lux of artificial light at night) for a complete oestrous cycle during the spring months was not significantly different from that in gilts maintained under normal daylight. Average ovulation rates were 13.4 for controls and 13.1 for treated gilts. A significant $(P<0.01)$ difference in ovulation rate was found between years.
\end{abstract}

Sykes (1956) has reported that reduced light decreases egg production in chickens, and McCluskey \& Parker (1963) reported delayed sexual maturity and lowered egg production in chickens maintained under reduced periods of light. Martinet (1963) and Pelletier \& Ortavant (1964) reported that sexual activity of the field vole and secretion of gonadotrophic hormones vary with season in both the male and female of this species. Furthermore, Martinet (1963), showed that sperm production and ovulation could be increased in the field vole with variation in the light-dark ratio. Thibault, Courot, Martinet, Mauléon, Du Buisson, Ortavant, Pelletier \& Signoret (1966) reviewed data showing that for certain species there appears to be an optimum duration of the daily light-dark ratio under which gametogenic activity is highest.

In view of the importance of the light-dark ratio on the reproductive processes of birds and certain mammals, this study was initiated to determine whether a continuous light regime for gilts for one oestrous cycle would alter ovulation rate significantly.

In Trial 1, conducted during the spring (April) of 1965, eighteen cycling Yorkshire gilts were divided equally between a control and a light group at an average age of $7 \frac{1}{2}$ months. The gilts were maintained on concrete-floored pens $2.4 \mathrm{~m}$ wide and $6.1 \mathrm{~m}$ deep with a roof covering one-half of the floor area. Gilts were group fed daily $2.72 \mathrm{~kg}$ of corn-soybean meal ration containing $15 \%$ alfalfa meal. The ration contained $14 \%$ protein and vitamins, and minerals were supplied to meet the National Research Council's (N.R.C., 1959) recommendations.

All gilts were checked daily with a boar and when found to be in oestrus were transferred to control or experimental pens of similar areas. The gilts to be subjected to light were placed in a pen equipped with lights. Light

* The investigation reported in this paper (No. 67-5-22) is in connection with a project of the Kentucky Agricultural Experiment Station and is published with approval of the Director. 
intensity at night was 130 lux in the centre and 118 lux at the sides of the pens about $0.5 \mathrm{~m}$ from the floor. Lights were turned on at 17.00 hours and off at 08.00 hours daily by an automatic switch. Control gilts were placed in pens not supplied with artificial light.

All gilts were maintained in the experimental pens throughout one oestrous cycle and were slaughtered 5 days after the first treatment oestrus. Immediately after slaughter the ovaries were removed, and the corpora lutea were counted to determine ovulation rate.

Trial 2 was conducted during April 1966 with a total of twenty cycling Yorkshire gilts (ten control and ten treated). Treatments and the experimental procedure were identical to that used for Trial 1. The data from both trials were subjected to analysis of variance.

The results from both trials are summarized in Table 1. There were no significant differences in ovulation rate between the gilts exposed to constant

TABLE 1

EFFECT OF EXPOSURE TO CONTINUOUS LIGHT FOR ONE OESTROUS GYCLE ON OVULATION RATE IN GILTS

\begin{tabular}{l|cc|cc}
\hline \multirow{2}{*}{ Item } & \multicolumn{2}{|c|}{ Trial } & \multicolumn{2}{c}{ Treatment } \\
\cline { 2 - 5 } \cline { 5 - 6 } & $1(1965)$ & $2(1966)$ & Control & Continuous light \\
\hline No. of gilts & 18 & 20 & 19 & 19 \\
Average ovulation rate & $14 \cdot 4^{*}$ & $12 \cdot 2$ & $13 \cdot 4$ & $13 \cdot 1$ \\
Average age at slaughter (days) & $244 \cdot 5^{*}$ & $256 \cdot 5$ & $251 \cdot 8$ & $249 \cdot 7$ \\
Average weight at slaughter (kg) & $130 \cdot 2^{*}$ & $112 \cdot 0$ & $120 \cdot 3$ & $120 \cdot 9$ \\
\hline
\end{tabular}

* Significant $(P<0.01)$ difference between trials.

light and the control gilts in either trial. Average ovulation rates for the control and treated groups were 13.4 and $13 \cdot 1$, respectively. Gilts in Trial 1 produced significantly $(P<0.01)$ more ova than those in Trial $2(14.4$ versus 12.2$)$, even though average ages at slaughter were 244.5 and 256.5 days, respectively. Average ages at slaughter for the control and treated groups did not vary significantly $(251.8$ versus 249.7 days). Gilts in Trial 1 were significantly $(P<0.01)$ heavier at slaughter than those in Trial $2(130.2$ versus $112.0 \mathrm{~kg})$. However, average weights of the gilts in the control and treated groups at slaughter were similar ( 120.3 and $120.9 \mathrm{~kg}$, respectively).

Seasonal differences in litter size in swine have been reported by Johansson (1929) and in ovulation rate in swine by Gossett \& Sorenson (1959). Warnick, Wiggins, Gasida, Grummer \& Chapman (1951) observed a difference between years in the age at onset of puberty in gilts (236 versus 251 days), and they also noted that within lines the faster growing gilts reached puberty at a younger age. The breeding of gilts in both trials in the present study was similar, and in view of the findings of Warnick et al. (1951), relative to the effect of weight at puberty, it appears that the heavier weight of the gilts in Trial 1 may partially account for the significant increase in ovulation rate. The significantly younger age at slaughter for the gilts in Trial 1 , along with the higher ovulation rate, seems to support the conclusion of Warnick et al. (1951) that within lines 
faster growing gilts tend to reach puberty at a younger age and that factors which tend to delay puberty also tend to depress ovulation rate.

Martinet (1963) showed that length of light exposure is a critical factor in normal reproduction in field voles. Spermatogenesis, as measured by testis weight, was lower in voles subjected to 5 or $10 \mathrm{hr}$ of light during the first 70 or 114 days of their life than in those subjected to $15 \mathrm{or} 20 \mathrm{hr}$ of daily light. In females, Graafian follicles and ovulation rates were significantly higher in voles receiving 15 versus 5 or $10 \mathrm{hr}$ of daily light. Thibault et al. (1966) reported that the optimum duration of daily light for highest gametogenic activity in sheep was 10 to $12 \mathrm{hr}$. Dutt (1965) reported that short-time exposure to continuous light during the sexual season tends to increase ovulation rate in ewes.

Results of the present study should not be interpreted as providing evidence that light has no influence on ovulation rate in swine. During April (spring) the amount of daily light may be sufficient to elicit optimum ovulation response in the cycling gilt, and it is possible that ovulation rate in swine may be lower during seasons with more restricted light periods. This hypothesis was not tested.

\section{REFERENCES}

Durt, R. H. (1965) Reproduction response in ewes after short-time exposure to light. (Abstract). 7. Anim. Sci. 24, 916.

Gossett, J. W. \& Sorensen, A. M., JR. (1959) The effects of two levels of energy and seasons on reproductive phenomena of gilts. F. Anim. Sci. 18, 40.

Johansson, I. (1929) Statistischer untersuchungen über die Fruchtbarkeit der Schweine. Z. Tierzucht. Zuchtungsbiol. 15, 49 (cited from S. A. Asdell, Patterns of Mammalian Reproduction. Comstock, Ithaca, New York. 1946).

Martinet, L. (1963) Etablissement de la spermatogenèse chez le campagnol des champs (Microtus arvalis) en fonction de la durée quotidienne d'éclairement. Annls Biol. anim. Biochim. Biophys. $3,343$.

McGluskey, W. H. \& Parker, J. E. (1963) The effect of length of daily light periods on reproduction in female chickens. Poultry Sci. 42, 1161.

N.R.G. (1959) Nutrient requirements of domestic animals, No. 2. Nutrient requirements of Swine. National Research Council, Washington, D.C.

Pelletier, J. \& Ortavant, R. (1964) Influence de la durée d'éclairement sur le centenu hypophysaire en hormones gonadotropes FsH et ICSH chez le bélier. Annls Biol. anim. Biochim. Biophys. 4, 17.

Sykes, A. H. (1956) Short day-lengths and egg production in the fowl. F. agric. Sci. 47, 429.

Thibault, C., Courot, M., Martinet, L., Mauléon, P., Du Buisson, F. du M., Ortavant, R., Pelletier, J. \& Signoret, J. P. (1966) Regulation of breeding season and estrous cycles by light and external stimuli in some mammals. 7. Anim. Sci. 25, 119 (Suppl.).

Warnick, A. C., Wiggins, E. L., Casida, L. E., Grummer, R. H. \& Chapman, A. B. (1951) Variation in puberty phenomena in inbred gilts. F. Anim. Sci. 10, 479. 